\title{
The Impact of Genre Based Instruction on EFL Learners' Writing Development
}

\section{Sirisuda Thongchalerm}

Ph.D candidate, corresponding author Faculty of Liberal Arts and Science, Kasetsart University, Kamphaeng Saen Campus, Thailand, sirisuda.t@ubru.ac.th

\section{Wisut Jarunthawatchai}

Asst. Prof., Department of English, Faculty of Liberal Arts and Science at Kasetsart University, Kamphaeng Saen Campus, Thailand, faaswsj@ku.ac.th

This study evaluated the effect of the teaching cycle adapted from the genre-based approach for teaching EFL learners in Thailand. As English writing is claimed to be the most serious problem among Thai EFL learners, the instruction aimed at developing writing competence of Thai EFL learners. One-group pretest-posttest design was employed in the study. The participants were 44 undergraduate students enrolling in a course of English writing for English teachers. This 12 week course aimed at teaching writing in the news report genre. After completing the course, two sets of tests were administered to measure their writing developments. The first test measured the students' development in linguistic features. The second test evaluated the students' performance in a writing task. A semi-structured interview was used to show students' attitudes towards the instruction. Quantitative results showed students made greater improvement in linguistic features and rhetoric organization, the majority of the students gained development at 'Moderately Improved' level. Qualitative results indicated students expressed positive attitudes towards autonomous and explicit learning. The students reflected that collaborative writing helped to improve their writing competence and increased their confidence in composing texts. The study concluded by stating the effectiveness of a genrebased approach to the development of EFL writing competence.

Keywords: genre-based approach, news reports genre, writing competence, genre learning cycle, linguistic and rhetoric structures

\section{INTRODUCTION}

As English language achieves the international status, it is practically a medium of communication among people from different countries. English has been taught as a compulsory subject in schools from the primary level to the tertiary level in Thailand.

Citation: Thongchalerm, S., \& Jarunthawatchai, W. (2020). The Impact of Genre Based Instruction on EFL Learners' Writing Development. International Journal of Instruction, 13(1), 1-16. https://doi.org/10.29333/iji.2020.1311a 
However, the National Test showed Thai students' proficiency in English language skills at a lower level than average and English writing was considered to be the lowest (Keyurawong, 2002; Wiriyachitra, 2002). Previous studies on English problems of Thai students found to be linguistic and communicative competence such as rhetoric, convention and organizations (Bennui, 2008; Sattayatham \& Ratanapinyowong, 2008; Watcharapunyawong \& Usaha, 2013). In addition, Iamla-Ong (2013) stated that English writing of Thai students is at highest level which agreed to Pawapatcharuadom (2007) who mentioned that writing is the most serious problem for Thai undergraduate students. $\mathrm{He}$ also stated the main issues of writing problems which were; writing with limited time; academic paper writings; the usage of grammatical rules in writings; and the development of content structures.

Watcharapunyawong \& Usaha (2013) revealed Thai EFL students' errors involved 16 categories: verb tense, word choice, sentence structures, articles, prepositions, modals/auxiliaries, singular/plural form, fragments, verb forms, pronouns, run-on sentences, infinitives/gerunds, transitions, subject-verb agreement, parallel structure, and comparison structure, respectively. Likewise, Bennui (2008) found the writing problems of Thai students were with "words, sentences and discourse, and these writing problems should be solved in an appropriate way for the quality of written product and EFL writing instruction."

Among writing pedagogies, the genre-based approach has been of great interest among EFL instructors in the last decades. Paltridge (2007) also claimed that students would remain to have writing convention issues if teachers did not bring these forms and patterns of language use to their conscious awareness. Genre approach was suggested to increase students' awareness of different ways of organizing information by discussing distinctive features of different purposeful texts. The process also supported students systemically to acquire a meta-linguistic awareness of the English language (Paltridge, 2001).

In addition, the teaching context in each country varies from place to place depending on the teaching and learning cultures. To implement a teaching approach for a particular course, the instructor needs to be aware of both classroom context and the teaching approach. Therefore, it is challenging to design the teaching cycle adapted from the genre based approach in this study which is based on the classroom context of Thailand in order to explore the impact of the approach in developing students' writing competence. 


\section{LITERATURE REVIEW}

\section{Genre}

Martin (2003) defined genre as "stated goal-oriented, and social processes" in spoken and written language. Genre characterized as language used in a conventionalized communicative setting in order to give expression to a specific set of communicative goals of a disciplinary or social institution. Genre includes sharing the name, communicative purposes, roles, context, convention, register cultural values and awareness (Bhatia, 2004; Johns, 1997).

\section{Genre Based Approach}

The genre-based approach is founded upon the notion that written discourse follows specific patterns or conventions of a text for a particular context (Nueva, 2013). Its successful application in writing pedagogies has been mentioned. The teaching and learning cycles of the genre-based approach vary regarding the schools of genre (New Rhetoric, Australian, and English for Specific Purpose).

The New Rhetoric genre has emphasized understanding text and the social functions of genres along with the contexts in which theses genres are produced (Hyon, 1996; Johns, 2003).

In Australian schools, genre is focused on social context and communicative rules which help develop "social capital" by providing the learners explicit instruction of a genre. (Johns, 2003; Martin, Christie, and Rothey, 1987; Feez and Joyce, 1998).

ESP genre is based on ideas that each text provides its own communicative purposes of text which shapes the schematic structures, content, and linguistic features. The implications of ESP genre in the language classroom in regards to the benefits of the writing model instruction that is it provides explicit teaching application (Hyland, 2004; Hyon, 1996).

Regarding the learning cycles developed based on genre pedagogy, Callaghan and Rothery (1988) proposed three phases of the learning cycle: deconstruction, joint construction and independent construction. Feez and Joyce (1998) proposed five stages: building the context; modeling; deconstructing the text; joint construction; and dependent construction and linking related texts. The cycles were developed based on the notion of scaffolding (Gibbons, 2002; Paltridge, 2001), as drawn from Vygotsky's (1978) view that higher thinking processes, including language, arise as a consequence of human interaction (Paltridge, 2001).

The merits of the genre based approach to writing pedagogy are that it facilitates the learners to develop awareness of both language features and contexts and also enhance students' understanding of how texts were organized. The direction was given concerning of audience choice and expectation in organizing the texts. It also enabled the students to learn how to write in a particular genre, to gain insight into how a particular genre fulfills a rhetorical purpose and to be aware of the various components 
of a text including the writer, the intended reader, and the text conventions based on communicative purposes (Badge \& White, 2000; Cheng, 2008; Devitt, 2004; Emily, 2005; Hyland, 2007; Johns, 2008; Yasuda, 2012).

Numerous studies employed genre analysis to writing pedagogy. Iddings \& Oliveira (2011) applied genre analysis to teach narrative writing for English language students. The study suggested that the teachers should integrates scaffolding cycles of genre analysis into the instruction because it helped students to be aware of content and target readers of each particular writing task. Likewise, Nagao (2018) stated that the teaching and learning cycles based on genre based approach enhance the EFL learners' awareness of generic structure and interpersonal meaning in writing. These results also support to Salehpir and Saeidi (2014) who mentioned that the approach helps scaffolding the sentence structure and writing frames in writing MA research papers. The approach equipped the students on how to convey the intended meaning and how to yield to the standard of research papers. In addition, Rezvani et al. (2015) investigated the effect of scaffolding genre based instruction of narrative writing on Iranian EFL learners' performance and revealed the efficacy of the approach which responded to the results of Ahn (2012) that the scaffolding activities at the early stages of the approach benefits the students in awareness of each genre. Since each text type is organized in different ways regarding its communicative purpose. The instruction based on the approach also improves L2 learners at primary level including enhancing the learners to be more confident and reflect positive attitudes towards learning writing. Furthermore, Kuiper et al. (2017) conducted a research on scaffolding tertiary students' writing using genrebased instruction. The results showed the benefits of genre based approach in improving the use of structure and linguistic features and also contribute the students' writing proficiency. Also Chaisiri (2010), Changpueng (2013), Lerdpreedakorn (2009), Rashidi and Mazdayasna (2016), Yang (2016) conducted researches which revealed that the students who had been through the GBI made great improvement in various aspects e.g. vocabulary, language, mechanics content and organization. Building genre awareness contributed to the learners' positive attitudes towards the teaching cycles including activities, and exercises and production of high quality texts.

However, some studies mentioned the drawbacks of the genre based approach. Uzun (2016) employed action research to develop EAP writing through GBI and indicated both positive and negative results. Although the results revealed that the learners showed a statistically significant increase in the use of communicative moves, a negative reflection of genre based approach is that it is time consuming at the early stages of the teaching and learning cycle. It requires a lot of time for the learners to practice writing of move structures part by part provided in a particular genre. Likewise, Byram (2004) stated that GBA may be inappropriate for active students because the instruction might spend much time on the knowledge of genre. Furthermore, the genre based approach may not take in to consideration the learners' insufficient knowledge of language and vocabulary to express what they are going to express to the readers (Byram, 2004; Dudley-Evans, 1995). Another disadvantage mentioned in the study was that the approach seemed to limit the ideas of the learners as the learners need to follow the move structures of a genre which agree to the result of Badge \& White (2000). 
Therefore, the effectiveness of genre based approach in L2 writing pedagogy seemed questionable and challenging for the writing instructors to design the courses or lessons based on the approach appropriate to the teaching and learning context.

\section{Research Questions}

The purpose of the study aimed to investigate the impact of genre based approach on developing EFL writing competence. Research questions were as follows:

RQ1. To what extend does the genre based instruction develop students' writing competence?

RQ2. What are the learners' reflections towards the instruction?

\section{METHOD}

The study investigated the impact of the teaching cycle adapted from genre based approach in developing the EFL students' writing competence. One - Group Pretest Posttest Design was employed in the study. After the instruction, the students were assigned to compose a news report with the information provided. Students were tested for linguistic improvement and attitude towards learning English language.

\section{Participants}

The participants were 44 second-year English major students enrolling in a course entitled Reading and Writing for English Teachers. They are 19-21 years old .They have studied English more than 12 years. The class and the research were handled by the researcher at Faculty of Education, Ubon Ratchathani Rajabhat University, Ubon Ratcthathani Province, Thailand.

\section{Teaching Cycle}

The teaching and learning cycle in this study was different from the cycle proposed by Rothery (1994) Feez and Joyce (1998) regard to the EFL classroom context of Thailand. Thus, the goal of teaching model was to develop language learners' communicative competence.

The teaching instruction was designed based on Vygotsky's notion of Zone of Proximal Development (ZPD) and scaffolding (Bruner, 1986). The teacher provided strong support at the early stages of learning. Thus, the practice stage was added in the learning cycle based on the teaching and learning culture, and the background knowledge of the Thai learners. This support was gradually and strategically removed as students' progress. As mentioned in many studies, peer teaching and discussion developed explicit understanding of the learners.

Based on the review of genre based approach and the situational context where the study was implemented, the teaching cycle of the approach was as follows;

Stage I: Modeling

1) Observation: studying models of news reports 
In the phase, the students were assigned to read the news reports from various news agencies to notice the language use, the sentence patterns and rhetoric of the news.

2) Analysis: analyzing the linguistic feature and organization (news elements)

In this phase, the students were assigned to work in groups to analyze the news elements which also called 'move' in genre analysis including tenses, punctuations, and sentence patterns used in each move. In addition, the students need to analyze the convention or the rhetoric of the news.

3) Practice: providing students with an explicit learning activity focusing of grammatical rules and structures used in the model text.

After the analysis activity, the students were provided with the worksheets in practicing the use of those features found in the analysis phase.

\section{Stage II: Construction}

1) Collaborative construction: In this phase, the students composed the news report in groups. Then, presented to the class. The students in the class comments, discussed and shared their opinions of news reports.

2) Independent construction: The students were assigned to write a news report genre

Stage III: Reflection: Reflections: The students discussed and reflected on the students' written tasks.

\section{Instruments}

The instruments used in this study were 2 sets of pretests and posttests which were employed before and after the implementation. T-test and Relative gain score were used to analyze the scores of the tests. A semi-structured interview was used to explore the students' reflection towards the instruction.

1. Linguistic Features Test (LF Test: 35 points)

The first set of pre-posttests emphasized the linguistic feature and structures used in the news report;

(1) Sentence structures

(2) Tenses

(3) Punctuation marks; commas, colons, semicolon, dashes, hyphens and apostrophes

(4) Quotations and reported speech, both indirect and indirect.

(5) Rhetoric and text convention including organization of the news report.

\section{News Report Writing Test (NR Test: 35 points)}

The second set was a news report writing task. The students were assigned to compose a news report with the provided information and the task was evaluated using a rubric by three raters. The rubric was based on the following components and aspects;

(1) Purpose of the news reports 
(2) Rhetoric of news reports

(3) Contents:

(4) News -supporting details

(5) News-Interesting

(6) Grammatical rules :The article is free from grammar and spelling errors

(7) Holistic:

3) Interview

The semi-structured interview aimed at investigating the students' attitudes and reflection of the teaching cycle was employed after the intervention.

\section{Data Collection Procedures}

The rubrics were developed based on the language uses and the purposes of the news report genre. To evaluate the text, the rubrics were provided to three readers; one native instructor and two nonnative English instructors; their average scores were used in this study.

\section{Data Analysis}

The study was conducted based on the hypothesis that the learners will be able to compose texts better after being equipped with explicit teaching of linguistic features;

-T-test and Relative Gain Score were used to analyze the quantitative data.

-Coding technique was used to analyze the interview data.

\section{FINDINGS}

This study presented the impact of genre based approach on developing students' writing competence. Firstly, the results of students' achievement after implementation of LF Test and NR Test were revealed. Then, the students' reflection to the teaching approach was also shown;

\section{Students' Writing Development}

\section{The Result of LF Test}

The first test (LF Test) focused on the language features used in the model text based on the result of genre analysis of news reports. This included sentence structures, quotation and reported speeches, tenses, punctuation, and rhetoric and organization (35 points).

Table 1

A comparison of mean scores for the pretest and posttest of LF Test

\begin{tabular}{|c|c|c|c|c|c|c|}
\hline \multirow{3}{*}{ LF TEST } & \multicolumn{2}{|c|}{ Pretest } & \multicolumn{2}{|c|}{ Posttest } & \multirow[b]{2}{*}{$\mathrm{t}$} & \multirow[b]{2}{*}{$\mathrm{p}$} \\
\hline & Mean & SD & Mean & SD & & \\
\hline & 14.31 & 3.97 & 20.38 & 4.7 & 13.12 & 0.00 \\
\hline
\end{tabular}

Table 1 reveals the students' mean scores from the pretest and posttest (LF Test) including the comparison. According to Table 1, the mean scores of each of the traits scored in the pretest was at 14.31, and in the posttest was at 20.38. The difference mean score was at 6.04 and the t-value was at 13.12 and the P-value was at .000 . This was a 
strong evidence suggesting that the approach of instruction employed in the study has improved students' achievement. The mean paired was markedly different from 6.04 and was statistically significant at the $95 \%$ confidence interval $(95 \% \mathrm{Cl}$.).

The assessment of writing competence revealed the students' development in writing skills in the linguistic features of grammatical rules sentence structures, and the ability in composing a text.

\section{The Result of NR Test}

To verify the effectiveness of the instruction, this study also employed the second set of tests to find out whether there was improvement of students' writing competence. The students' result scores of NR test was as follows;

Table 2

A comparison of mean scores for the pretest and posttest of NR Test

\begin{tabular}{|c|c|c|c|c|c|}
\hline Aspect & & Mean & SD & $\mathrm{t}$ & $\mathrm{P}$ \\
\hline \multirow{2}{*}{$\begin{array}{l}\text { 1. Purpose of the news } \\
\text { report }\end{array}$} & Pretest & 2.84 & 0.43 & \multirow{2}{*}{13.75} & \multirow{2}{*}{0.00} \\
\hline & Posttest & 3.84 & 0.43 & & \\
\hline \multirow{2}{*}{ 2. Rhetoric of news report } & Pretest & 1.86 & 0.55 & \multirow{2}{*}{19.71} & \multirow{2}{*}{0.00} \\
\hline & Posttest & 4.29 & 0.70 & & \\
\hline \multirow{2}{*}{ 3. Content } & Pretest & 2.20 & 0.59 & \multirow{2}{*}{16.60} & \multirow{2}{*}{0.00} \\
\hline & Posttest & 4.09 & 0.60 & & \\
\hline \multirow{2}{*}{ 4. News- supporting details } & Pretest & 3.04 & 0.21 & \multirow{2}{*}{16.96} & \multirow{2}{*}{0.00} \\
\hline & Posttest & 4.64 & 0.61 & & \\
\hline \multirow{2}{*}{ 5. News-Interesting } & Pretest & 1.89 & 0.38 & \multirow{2}{*}{25.78} & \multirow{2}{*}{0.00} \\
\hline & Posttest & 2.90 & 0.36 & & \\
\hline \multirow{2}{*}{ 6. Grammatical rule } & Pretest & 1.98 & 0.34 & \multirow{2}{*}{21.39} & \multirow{2}{*}{0.00} \\
\hline & Posttest & 4.86 & 0.85 & & \\
\hline \multirow{2}{*}{ 7. Holistic } & Pretest & 2.45 & 0.81 & \multirow{2}{*}{16.54} & \multirow{2}{*}{0.00} \\
\hline & Posttest & 4.79 & 0.83 & & \\
\hline
\end{tabular}

The data above indicated that the students improved on grammatical rules, rhetoric organization and holistic and contents of the text respectively based on the increased scores in posttest.

In addition, the data from the interview reported that students acquired the language features at the model analysis stage. With the additional exercises and drills the teacher provided after the model analysis, the learners develop their writing competence as they noticed the features on the model analysis stage.

\section{Growth of knowledge}

In addition to the Results of LF Test and NR Test presented above, the scores from those two tests were used to evaluate the students' growth of knowledge or so-called relative gain score to measure the students' progress.

Kanjanawasee (1989) proposed the simple and reliable formula to measure the students' growth of knowledge as the following formula;

$$
\mathrm{G}=\frac{(\mathrm{Y}-\mathrm{X}) \times 100}{(\mathrm{~F}-\mathrm{X})}
$$


(G : Growth score; X : Pre-test score ; Y: Posttest score; F : Maximum (Full score)

The scores from each student were used to measure their progress with the ratio;
$0-25 \%$
$26-50 \%$
- $\quad$ Slightly improved
$51-75 \%$
Moderately Improved
$76-100 \%$
- $\quad$ Markedly Improved
- $\quad$ Exceptionally Improved

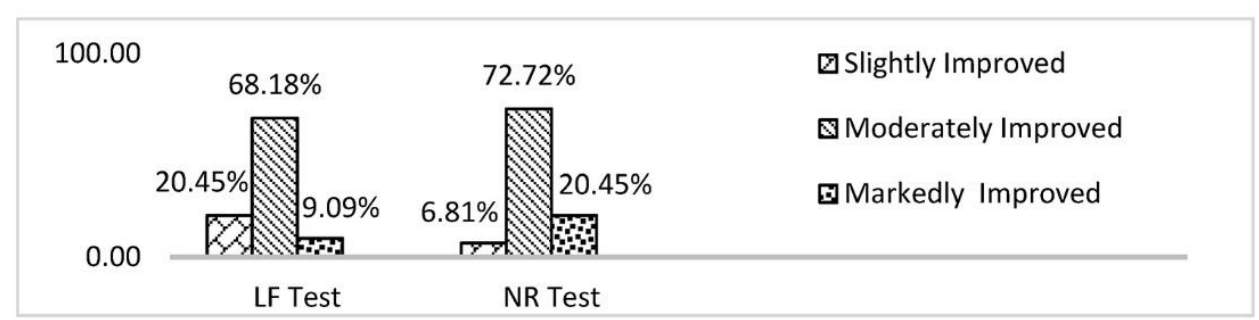

Figure 1

Percentage of gain score of Test I: LF Test and Test II: NR Test

The table above presents the students' relative gain scores. It indicates the students' development after the intervention. 10 of 44 students had developed at 'Slightly Improved' level. The majority of students (30 of 44) had made 'Moderately Improved' level, and 4 of 44 students had improved at Markedly Improved' level. These revealed that the students have developed their writing competence after the instruction. None of the students has reached 'Exceptionally Improved' level.

According to relative gain scores from NR Test, the students' development is indicated. The majority of the students (30 of 44) developed in writing ability at 'Moderately Improved' level or the gain score is between $25-50 \%$. Some (9 of 44) showed their development in the posttest (NR Test) at "Markedly Improved' level or the percentage of the relative gain score is between $50-75 \%$. Few of them (3 of 44) had 'Slightly Improved' progress in the posttest comparing to the posttest. None of the students has reached 'Exceptionally Improved' level.

Based on the results shown above, the majority of students had developed at the 'Moderately Improved' level. Thus, the instruction based on genre based approach can develop the students' competence both in linguistic competence and the writing competence.

In addition, the data from the interview reported that students acquired the language features at the model analysis stage. With the additional exercises and drills the teacher provided after the model analysis, the learners developed their writing competence as they noticed that features in the model analysis stage and the practicing phase. These two phases provided the learners' explicit learning of the language features. 


\section{Students' Reflection}

After completing the course, 15 of 44 students were randomly interviewed with 5 representatives of each group. The first group was the students who were in "Markedly Improved" group, the second were those who were in "Moderately Improved" progress level, and the last group were students in "Slightly Improved" group.

The results from the interviews showed students' refection towards the instruction as follows;

\section{Linguistic competence:}

The students stated that they acquired progress in English writing especially in terms of grammatical rules and structures. They revealed that the modeling stage enhanced their ability to cope with the linguistics features, contents, and organization. Studying model texts gave them insight into the purpose of learning those linguistic features to be able to compose texts as a model. As the student revealed;

"The first I felt like trying to imitate structures, but I realized that it was a way to cope with the structures. I had a chance to practice writing each types of structure which developed my ability in writing English and also developed my English competence."

"I like the analyzing model texts. It makes me to know what to do with my text. I can follow the move structures of texts. I know what kind of sentences I need to write and what contents I need to provide and organize them to make the readers understand my text easy."

\section{Writing competence:}

The students also stated that the method of instruction eased them into writing; they learned what information was needed for each genre and the organization. For example, some of them reported:

"It helped me in organizing sentences and text."

Some students also reflected:

"I realized my writing is better and I learned the weaknesses of my previous texts after learning about genre", "I learned what to write and what tenses and structures to use and complete my texts easier comparing to the past".

They also reported that language choice is a crucial factor supporting the text to achieve a communicative purpose for particular contexts. In addition, most of the students also stated that the learning cycle of the method enhanced them to edit their mistakes and to revise the text organization.

\section{Genre knowledge transferring:}

Most of the students reported on the question of transferring knowledge of the learning cycle to use in other writing tasks as follows:

"When I am assigned to write another text in other subjects, I can find the model texts, then study the language use in the models and compose my own texts".

This response indicated that this student was confident that they could transfer the method of genre analysis to explore unfamiliar texts and find more exercises on language features to practice. 
This response was an evidence indicating the genre-based approach supported autonomous learning and develop writing competence.

\section{Positive attitude:}

Students reported in the interview that they had positive responses to the instruction. They stated that the leaning cycle developed their writing performance as follows:

"I felt that my writings were more effective".

They revealed that the genre-based approach enhanced collaborative learning, a goal which was appropriate for the learning culture of Thai students:

"I like collaborative writing stage the most. I enjoyed learning writing and it makes me confident when I have to write individually",

"I had learned more on structures and how to organize the text by discussing with friends. So, when I have to write the texts individually, I am confident and I'm not stressed while composing the texts". ,

"I like the collaborative learning activities the most, I think it support my leaning as well".

Working in collaborative writing groups fulfilled the students need for clear understanding in the language use, from discussing and sharing ideas to composing the text. They reported that they enjoyed learning with peers. The activity of collaborative writing also made the students confident in composing the task during the individual writing stage because they had experienced it. Genre-based approach also provided scaffolding activities which supported students learning as the approach developed based on Vygotsky's “zone of proximate development" (ZPD), the gap between a level of individual performance and potential performance (Vygotsky,1978).

However, one of the students revealed negative attitude that;

"I think the model framed my thought like a strict rules.... Sometimes I wondered why I had to organize my text as the model text. I may have my own style in composing the news."

After the student mentioned the negative attitude, the teachers reminded her of the concept of discourse community and the expectation of the readers to achieve the communicative goal. The student realized that case, and learned how the genre knowledge shaped the text convention in a particular communicative situation.

\section{DISCUSSION}

The results revealed that the teaching cycle based on genre based approach developed Thai EFL wring ability. The results of LF Test and NR Test indicated the effectiveness of the genre based approach on developing students writing competence. The statistic evidence revealed that the instruction based on genre based approach developed students on linguistic features and rhetoric organization in writing a particular text. These results response to those genre practitioners which stated that genre based approach provides explicit instruction of linguistic feature and scaffolding activities for 
the learners. With the explicit and collaborative learning, the students also revealed positive attitude towards the learning cycle. It promoted the learners to succeed in developing writing skills (Callaghan and Rothery, 1988; Feez, 2002; Feez and Joyce, 1998; Hyon, 1996).

In addition, the results also supported the results of the previous studies (e.g. Ahn , 2012; Albino, 2015) that the teaching cycle developed students on genre awareness, linguistic and rhetoric knowledge in writing. The findings also agreed that genre based approach supports the students on grammatical structures, schematic structures and the use of information to support the text, and improved their writing ability. Furthermore, the approach promoted the structures with the explicit learning on linguistic structures and supported students' ability to compose tasks effectively. Based on the relative gain scores, most of the students' growth knowledge were at 'Moderately Improved' level. It also improved students' written outputs in terms of contents, text organization, and sentence structures. These results also responded to other studies investigating the effective of genre based approach e.g. Krisnachinda (2006), Nueva (2013), Ueasiriphat (2019) and, Ying (2016).

Regarding the drawbacks of the approach, it takes time in the early stages of teaching and learning cycle including the explicit teaching of the linguistic feature, and the genre knowledge. This study found that it depends on the instructors to design the activities and the exercise. To cope with the linguistic features, it takes time for some to acquire new knowledge. To practice using those features is a crucial stage to enhance the students in writing competence. However, in this study the students reflected the positive attitude to this stage as it helped develop their writing ability as mentioned. The studies of Srinon (2010) and Chaisiri (2010) clearly claimed that students needed support and the knowledge of the genres learned at the early stage. This implies that the instructional process needs to be adjusted appropriately to assist students based on their prior knowledge. Another argument is that the approach limits the learners' ideas. Although the students' need to follow the move structure and use the linguistic features they had learned to compose the texts, their creative ideas were found in other aspects e.g. the students' ideas in creating news with some information provided. Thus, the instructors can design interesting activities for enhancing the students' creative thinking and also for active leaners.

\section{CONCLUSION}

This study sought to evaluate the genre-based approach in developing English writing in Thai EFL contexts. The results indicated that the genre-based approach was effective in developing students' writing competence. The participants improved their writing ability after the intervention. They showed the development of linguistic competence, genre knowledge and writing performance, which contribute communicative competence to the learners'. The study reported that the students had higher achievement on grammatical rules, rhetoric organization including holistic and contents of the text respectively. The result of this study confirmed the findings of previous studies in improving students' written outputs in terms of content, text organization, and sentence structure. The statistics reported that the approach developed the students' linguistic 
features and rhetoric awareness which affected the students' writing skill improvement. Most of the learners reported a positive attitude towards the teaching model. They reflected that the instruction developed their English writing competence including genre awareness. On the other hand, the study also found a negative reflection of the approach due to the limitation of the patterns or the writing style. Students concluded that the teaching cycle was appropriate to Thai EFL classroom contexts. The modeling stage and construction stage benefited the development of writing ability especially in the practicing and collaborative construction stages. The practicing stage provided the explicit teaching on linguistics features that supported the language use. The collaborative construction stage helped to gain confidence in composing texts by offering a chance to discuss and share ideas with peers. The approach supported autonomous learning by encouraging students to apply the activities in genre based learning cycle to self-study when being assigned to compose in different genres.

The results of the study also suggested pedagogical implications in developing teaching EFL writing materials. Teachers can design particular writing tasks, such as worksheets and instructional package to support students' explicit learning of linguistic features. The scaffolding activities or materials used in EFL classroom benefit the students in their self-learning. They can learn step by step to cope with the target language in order to make them confident in the learning progress.

\section{REFERENCES}

Ahn, H. (2012). Teaching writing skills based on a genre approach to L2 primary school students: An action research. English Language Teaching, 5(2), 2-16.

Albino, G. (2015). The Effect of an Explicit Genre-Based Approach to teaching Workplace Writing. EdD thesis The Open University.

Badge, R., \& White, G. (2000). Product, Process and Genre. ELT journal. 54(2), 156260 .

Bennui, P. (2008). A study of L1 interference in the writing of Thai EFL students. Malaysian Journal of ELT Research, 4, 72-102.

Bhatia, V. K. (2004). Worlds of Written Discourse: A Genre-based View. In Advances in Applied Linguistics. Eds. Chris Candlin and Srikant Sarangi. London: Continuum.

Bruner, J. (1986). Actual Minds, Possible Worlds. Cambridge, MA: Harvard University Press.

Boonyarattanasoontorn, P. (2017). An investigation of Thai students' English language writing difficulties and their use of writing strategies. Journal of Advanced research in Social Science and Humanities, 2(2), 111-118.

Byram, M. (2004). Genre and genre-based teaching. The Routledge Encyclopedia of Language Teaching and Learning (pp. 234-237). London: Routledge.

Callaghan, M., \& Rothery, J. (1988). Teaching factual writing: A genre based approach. Mauriceville, N.S.W.: DSP Literacy Project, Metropolitan East Region. 
Chaisiri, T. (2010). Implementing a Genre Pedagogy to the Teaching of Writing in a University Context in Thailand. Language Education in Asia, (1)

Changpueng, P. (2013). The Effects of the Genre-Based Approach on Engineering Students' Writing Ability. Thesis, University of Technology North Bangkok, Thailand.

Cheng, F. (2008). Scaffolding language, scaffolding writing: A genre approach to teaching narrative writing. Asian EFL Journal, 10(2), 253-274.

Devitt, A. (2004). Writing Genre. Southern Illinois: Carbondale.

Dudley-Evans T. (1995). Common-core and specific approaches to the teaching of academic writing. In D. Belcher \& G. Braine (Eds.), Academic writing in a second language, 293-312

Feez, S., \& Joyce, H. (1998). Text-based Syllabus Design. Sydney: National Centre for English Language Teaching and Research, Macquarie University.

Feez, S. (2002). Heritage and innovation in second language education. In A. M. Johns (Ed.), Genre in the classroom: Multiple perspectives (pp. 43-69). Mahwah, NJ: Lawrence Erlbaum Associates.

Gibbons, P. (2002). Scaffolding Language, Scaffolding learning: Teaching Second Language Learners in the Mainstream Classroom. U.S.A.: Heinemann.

Hyland, K. (2004). Genre and second language writing. Michigan, US : University of Michigan Press

Hyland, K. (2007). Genre pedagogy: Language, literacy, and L2 writing instruction. Journal of Second Language Writing, 16, 148-168.

Hyon, S. (1996). Genre in three traditions: Implications for ESL. TESOL Quarterly, 30, 693-722

Iamla-ong, H. (2013). "Language Learning Problems and Language Learning Strategies of MFU Students." MFU Connexion 2(1): 58-91.

Iddings, J., and De Oliverira, L. (2011) Applying the Genre Analysis of Narrative to the Teaching of English Language Learners. INTESOL Journal. 8(1),25-39

Johns, A. (2003). Genre and ESL/EFL composition instruction. In B. Kroll (Ed.), Exploring the dynamics of second language writing. Cambridge: Cambridge University Press. pp. 195-217

Johns, A. M. (2008). Genre awareness for the novice academic student. An Ongoing Quest: Language Teaching, 41, 237-252

Kanjanawasee, S. (1989) Alternative strategies for policy analysis: an assessment of school effects on students' cognitive and affective mathematics outcomes in lower secondary schools in Thailand, Dissertation, University of California: Los Angeles. 
Keyuravong, S. (2002). English language instruction in universities is about to get an overhaul. Thai TESOL Focus, 15(1), 10.

Kuiper, C., Smit, J., De Wachter, L., \& Elen, J. (2017). Scaffolding tertiary students' writing in a genre-based writing intervention. Journal of Writing Research, 9(1), 27-59. DOI: $10.17239 /$ jowr-2017.09.01.02

Lerdpreedakorn, N. (2009). Genre-based Approach to Teaching Academic Writing. In A. M. Stoke (Ed.), JALT2008 Conference Proceedings: Tokyo: JALT

Ministry of Education MOE, (1996). Educational Reform at the Ministry of Education (1996-2007). Bangkok: Ministry of Education.

Nagao, A. (2018). A Genre-Based Approach to Writing Instruction in EFL Classroom Contexts. Canadian Center of Science and Education: English Language Teaching, $11(5), 130$.

Nueva, J. (2013) Genre-based Instruction: Its Effect on Students' News Article, Proceedings Conference of the 3th International Conference on Foreign Language Learning and Teaching. Language Institute. Thammasat University, 338-350.

Paltridge, B. (2001). Genre and the Language Learning Classroom. Ann Arbor: University of Michigan Press.

Pawapatcharaudom, R. (2007). An Investigation of Thai Students' English Language Problems and Their Learning Strategies in the International Program at Mahidol University. Masters' thesis, King Mongkut'sInstitute of Technology, Bangkok, Thailand

Phichiensathien, P. (2016). Genre-based Approach in Academic English Writing. PASAA PARITAT, 31.

Rashidi, N., \& Mazdayasna, G. (2016). Impact of Genre-Based Instruction on Development of Students' Letter Writing Skills: The Case of Students of Textile Engineering. Journal of Research in Applied Linguistics, 7(2), 55-72.

Salehpour, S.\& Saeidi, M. (2014). The Effect of Genre-based Scaffolding on Research Paper Writing of MA Candidates in an EFL Context. Journal of English Language Pedagogy and Practice, 7(15), 91-112.

Sattayatham, A., \& Honsa Jr, S. (2007). Medical students' most frequent errors at Mahidol University, Thailand. Asian EFL Journal, 9(2), 170-194

Srinon, U. (2010). An investigation of generic structure development on the introduction of a genre-based approach into a Thai university's academic writing context. Proceeding of the ASFLA Conference, Practicing Theory: Expanding Understanding of Language, Literature and Literacy, held at the Queensland University of Technology, Brisbane 30 September -2 October.

Ueasiriphan, T., \& Tangkiengsirisin, S. (2019). The Effects of Genre-Based Teaching on Enhancement of Thai Engineers' Technical Writing Ability. International Journal of Instruction, 12(2), 723-738. https://doi.org/10.29333/iji.2019.12246a 
Uzun, K. (2016). Developing EAP Writing Skills through Genre-Based Instruction: An Action Research. The International Journal of Educational Researchers (IJERs), 7(2), 25-38

Vygotsky. L. (1978). Mind in Society. Cambridge MA: Harvard University Press.

Watcharapunyawong, S., \& Usaha, S. (2013). Thai EFL students' writing errors in different text types: The interference of the first language. English Language Teaching, 6(1), 67-78.

Wiriyachitra, A. (2002). English language teaching and learning in Thailand in this decade. Thai TESOL Focus, 15(1), 4-9.

Yasuda, S. (2012). Exploring changes in FL writers' meaning-making choices in summary writing: A systemic functional approach. Journal of Second Language Writing, 27, 105-121. http://doi. org/10.1016/j.jslw.2014.09.

Yang, Y. (2016) A study of Sydney School's Genre- Based Pedagogy in Chinese College English Education: Studies in Sociology of Science, 7(1), 32-38. 